\title{
Sustainability of Women's Employment Rate for
}

\section{Malaysian Economic Development}

\author{
Aye Aye Khin ${ }^{\mathrm{a}}$, Mei Peng Low ${ }^{\mathrm{b}}$, Moe Shwe Sinc, Seethaletchumy Thambiah ${ }^{\mathrm{d}}$ \\ \& Soh Chong Yu
}

\begin{abstract}
This research paper develops a model for the sustainability of women's employment rate in Malaysia's economic development. This study examined annual data from 1982 to 2018, with 37 observations. A new econometric method was adopted to determine both short-run and long-run relationships among the variables using the Johansen Cointegration rank test, Vector Error Correction Method (VECM) with error correction model of cointegration equation. The VECM results revealed significant and positive short-term relationships between foreign direct investment, gross domestic product (GDP), and the negative short-term relationship of the lagged period of women's employment rate to women employment rate (WER). The variables, GDP, education level, and women's marital status are cointegrated and have a long-term relationship between WER in the cointegration equation. The Johansen Cointegration rank test also showed the existence of cointegration equations, and a long-term relationship between the variables. Eventually, the residual diagnosis, significant error term, and the performance of the model evaluation were found as satisfactory and valid. In short, this research paves the way for policymakers to construct a better policy for the future of women's employment sustainability.
\end{abstract}

Keywords: Women's employment rate; Malaysian economic development; Johansen cointegration rank test; Vector Error Correction Method; Cointegration.

JEL Classification: J21, O11, C3, C32, C4

a Corresponding author. Faculty of Accountancy and Management (FAM), Universiti Tunku Abdul Rahman (拉曼大學), Jalan Sungai Long, Bandar Sungai Long, Cheras, 43000 Kajang, Selangor, Malaysia.Email: ayekhin@utar.edu.my; Orcid ID: 0000-0002-3401-4043.

b Faculty of Accountancy and Management (FAM), Universiti Tunku Abdul Rahman (拉曼大學), Jalan Sungai Long, Bandar Sungai Long, Cheras, 43000 Kajang, Selangor, Malaysia. Email: lowmp@utar.edu.my; Orcid ID: 0000-0002-3141-3081.

c Faculty of Business, Economics and Social Development (FBESD), Universiti Malaysia Terengganu (UMT), 21030 Kuala Terengganu, Terengganu, Malaysia. Email: moe.sin@umt. edu.my; Orcid ID: 0000-0002-9170-8949

d Faculty of Management (FOM), Multimedia University (MMU), Cyberjaya, Selangor, Malaysia. Email: seethaletchumy@mти.edu.my.

e Faculty of Accountancy and Management (FAM), Universiti Tunku Abdul Rahman (拉曼大學), Jalan Sungai Long, Bandar Sungai Long, Cheras, 43000 Kajang, Selangor, Malaysia. Email: dominicsohcy@gmail.com. 


\section{Introduction}

According to Martins (2021), an individual is in employment in a given month if there is a registration of employment contributions corresponding to at least one day of work. On the other hand, an individual is in subsidised unemployment in a given month if there is no registration of employment contributions in that month. Additionally, employment is generally accepted as a relationship between two parties, namely the employer and the employee. The employee works for the employer with a stipulated amount of wage. The Star Online (2018) reported that there is an increase in female labour participation rates from $37.4 \%$ to $38.8 \%$ in Malaysia, from the year 2013 to the year 2018. This incremental rate reveals a positive effect to Gross Domestic Product (GDP) growth, with an increase of $0.3 \%$. Qinfen (2017) mentioned that high female labour participation rate can improve labour productivity, eradicate poverty, and enhance the overall socioeconomic development. Based on the Department of Statistics Malaysia (DOSM, 2021), the labour force participation rates for both men and women from the year 2013 to the year 2019 in Malaysia are reported in Table 1. It highlights that the labour force participation rate for women gradually increased annually from $37.4 \%$ in 2013 to $38.9 \%$ in 2019 . However, the increase in the labour force participation rate of women was far lower compared to the male labour force participation rate.

Table 1: Malaysia - Male and Female Labour Force Participation Rate (\%), 2013-2019

\begin{tabular}{cccccccc}
\hline Year & $\mathbf{2 0 1 3}$ & $\mathbf{2 0 1 4}$ & $\mathbf{2 0 1 5}$ & $\mathbf{2 0 1 6}$ & $\mathbf{2 0 1 7}$ & $\mathbf{2 0 1 8}$ & $\mathbf{2 0 1 9}$ \\
\hline Male & 62.6 & 61.9 & 61.8 & 61.6 & 61.6 & 61.2 & 61.1 \\
Female & 37.4 & 38.1 & 38.2 & 38.4 & 38.4 & 38.8 & 38.9 \\
\hline
\end{tabular}

Source: DOSM (2021).

Besides, between 1987 to 2019, the Malaysian economy was also undergoing economic structural transformation, from an agriculturebased economy to a manufacturing-based economy, as shown in Table 2. According to Table 2, RM316,320 million of GDP, was contributed by the manufacturing sector in the year 2019. Whereas RM101,549 million of GDP was recorded by the agriculture, livestock, forestry and the fishing sector, while the utilities sector contributed the lowest with RM38,254 million for 
the same year. From the year 1987 to 2019 (DOSM, 2021), the female labour participation rate in the agricultural sector has also reduced from $76.7 \%$ to $14.1 \%$. On the other hand, the female labour participation rate has started to increase in the manufacturing sector from $4.3 \%$ to $27.1 \%$, sales sector from $4 \%$ to $22.1 \%$ and service sector from $11.2 \%$ to $27.4 \%$, accordingly.

Table 2: Malaysia - GDP by Economic Activity at Current Prices, 1987-2019 (RM, million, at current prices)

\begin{tabular}{|c|c|c|c|c|c|c|}
\hline Year & $\begin{array}{l}\text { Agriculture, } \\
\text { Livestock, } \\
\text { Forestry } \\
\text { and Fishing }\end{array}$ & $\begin{array}{c}\text { Mining } \\
\text { and } \\
\text { Quarrying }\end{array}$ & Manufacturing & Construction & Utilities & $\begin{array}{l}\text { Wholesale and } \\
\text { Retail Trade, } \\
\text { Accommodation, } \\
\text { Food and } \\
\text { Beverage }\end{array}$ \\
\hline 1987 & 16,185 & 10,235 & 16,058 & 2,818 & 2,129 & 8,720 \\
\hline 1988 & 18,540 & 10,107 & 20,157 & 2,866 & 2,300 & 10,689 \\
\hline 1989 & 19,028 & 10,796 & 25,048 & 3,475 & 2,568 & 13,297 \\
\hline 1990 & 18,120 & 14,111 & 28,847 & 4,649 & 2,643 & 16,171 \\
\hline 1991 & 19,398 & 13,725 & 34,524 & 5,939 & 2,708 & 19,404 \\
\hline 1992 & 21,958 & 12,399 & 38,910 & 7,396 & 3,295 & 22,238 \\
\hline 1993 & 23,741 & 11,037 & 44,643 & 9,054 & 4,289 & 25,924 \\
\hline 1994 & 26,702 & 10,426 & 52,072 & 10,909 & 4,858 & 30,186 \\
\hline 1995 & 28,809 & 13,864 & 58,684 & 13,747 & 5,813 & 34,132 \\
\hline 1996 & 29,637 & 16,598 & 70,646 & 16,641 & 6,560 & 37,794 \\
\hline 1997 & 31,283 & 19,432 & 79,974 & 18,474 & 7,726 & 41,529 \\
\hline 1998 & 37,706 & 19,055 & 81,525 & 14,507 & 9,188 & 43,169 \\
\hline 1999 & 32,610 & 23,081 & 93,045 & 13,987 & 9,619 & 44,378 \\
\hline 2000 & 30,647 & 37,617 & 109,998 & 13,971 & 10,629 & 47,934 \\
\hline 2001 & 28,245 & 33,945 & 103,434 & 14,241 & 11,281 & 49,201 \\
\hline 2002 & 34,432 & 34,169 & 112,076 & 14,673 & 11,970 & 51,326 \\
\hline 2003 & 38,971 & 41,918 & 125,332 & 15,200 & 12,607 & 53,062 \\
\hline 2004 & 43,949 & 56,881 & 144,007 & 15,458 & 13,711 & 59,401 \\
\hline 2005 & 44,912 & 72,111 & 149,754 & 16,107 & 14,076 & 74,641 \\
\hline 2006 & 51,383 & 81,759 & 164,510 & 16,451 & 14,878 & 81,528 \\
\hline 2007 & 66,446 & 88,332 & 173,804 & 18,739 & 15,840 & 95,353 \\
\hline 2008 & 76,753 & 120,170 & 189,105 & 21,156 & 16,855 & 114,197 \\
\hline 2009 & 65,719 & 81,342 & 169,661 & 23,187 & 17,852 & 115,263 \\
\hline 2010 & 82,882 & 89,793 & 192,493 & 28,213 & 22,173 & 134,634 \\
\hline
\end{tabular}




\begin{tabular}{ccccccc}
\hline Year & $\begin{array}{c}\text { Agriculture, } \\
\text { Livestock, } \\
\text { Forestry } \\
\text { and Fishing }\end{array}$ & $\begin{array}{c}\text { Mining } \\
\text { and } \\
\text { Quarrying }\end{array}$ & Manufacturing & Construction & Utilities & $\begin{array}{c}\text { Wholesale and } \\
\text { Retail Trade, } \\
\text { Accommodation, } \\
\text { Food and } \\
\text { Beverage }\end{array}$ \\
\hline 2011 & 104,424 & 95,905 & 212,618 & 30,892 & 23,676 & 151,000 \\
2012 & 95,122 & 101,474 & 224,730 & 37,909 & 25,699 & 161,393 \\
2013 & 92,830 & 103,484 & 232,659 & 42,692 & 27,443 & 174,765 \\
2014 & 98,177 & 109,064 & 253,087 & 48,650 & 30,940 & 197,585 \\
2015 & 97,539 & 103,059 & 262,379 & 55,382 & 31,710 & 220,241 \\
2016 & 93,977 & 105,368 & 273,899 & 59,508 & 33,412 & 234,539 \\
2017 & 99,509 & 105,838 & 290,464 & 63,522 & 34,396 & 251,633 \\
2018 & 99,579 & 103,512 & 304,843 & 66,194 & 36,079 & 272,660 \\
2019 & 101,549 & 101,438 & 316,320 & 66,266 & 38,254 & 292,221 \\
\hline
\end{tabular}

Source: DOSM (2021).

Many past studies (Chant \& Sweetman, 2012; Duflo, 2012) have produced congruent findings that the participation of women in the labour force would lead to increased national economic development. By increasing the women's employment rate, it could substantially generate significant GDP contribution (Bryant, Jacobsen, Bell, and Garrett, 2004). Besides, women's participation in the labour force will reduce the inequality gap with the counterparts and drive sound economic development. Henceforth, it is critically important to develop a model for the women's employment rate, particularly in the Malaysian context. Therefore, this research paper adds value to the body of knowledge by providing insightful findings of the women's employment rate in Malaysia's multi-racial context. It is also deemed timely to examine the women's employment rate using the robust statistical tests of Vector Error Correction Method (VECM) and Johansen Cointegration Rank Test. Osundina (2020) explained that females with higher education and appreciable health statuses have better chances of participating in the labour force. In a nutshell, the purpose of this research was to study how net-flow of foreign direct investment (FDI), GDP growth rate, educational level (EDU), marital status (MARS), and fertility rate (FR) affect the sustainability of the women's employment rate (WER) in the Malaysian economy development nowadays and in the future. Due to the advancement of technology, whether the women's employment rate will increase in the future is enigmatic. 
Therefore, Figure 1 shows the WER, net-flow of FDI, GDP growth rate (GDP), EDU, MARS, and FR from the year 1982 to 2018 in Malaysia. The WER had slightly decreased from $96.78 \%$ in 2014 to $96.37 \%$ in 2018 . Moreover, net-flow of FDI, GDP growth rate, and fertility rate (FR) were also decreasing. On the other hand, educational level (EDU) and women's marital status (MARS) increased year by year accordingly.

Figure 1: Malaysia - WER, FDI, GDP, EDU, MARS and FR, 1982-2018 (\%)

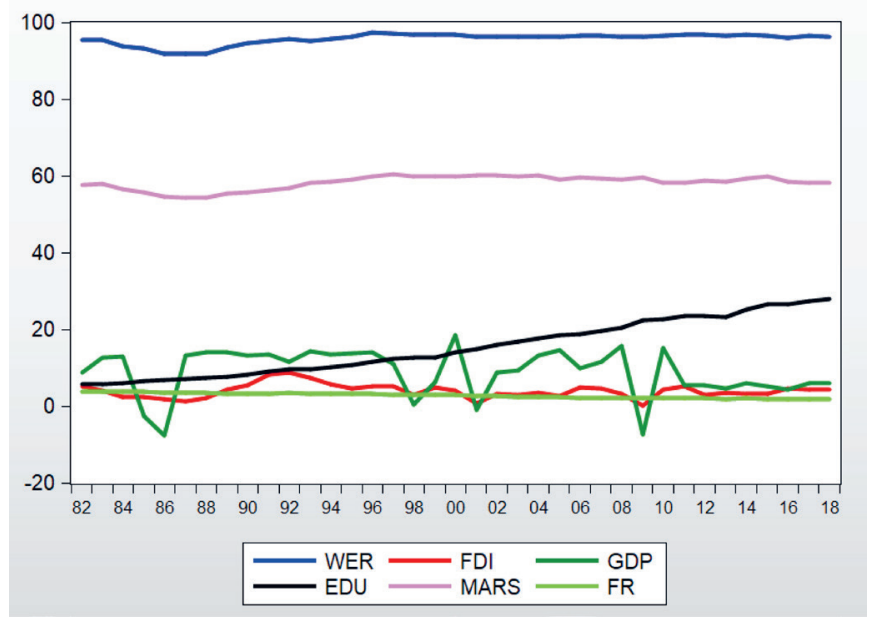

Source: DOSM (2021).

\section{Literature Review}

This research identified the contributing factors of women's employment in various industries in Malaysia. Thus, it empirically examined the behaviours and the relationships between the variables. These variables include WER, FDI, GDP, EDU, MARS and FR.

\subsection{Women's employment rate (WER)}

Employment rate refers to the number of people in employment as a percentage of the working age population. Women's employment is any work for pay or profit in which women are engaged (Gemelli, 2014). The number of women employed varies by country or region. For example, 
women made up about $45 \%$ in the countries of the European Union, and less than $30 \%$ of the paid workforce in Northern Africa and Western Asia, accordingly (Gemelli, 2014). Organisation for Economic Co-Operation and Development (OECD) reported that in its member countries, the employment rates were $13 \%$ lower for women than for men. The availability of occupations to women is impacted by their race, class background, immigrant status, and marital status as well (Raman, Anantharaman and Jayasingam, 2008). They are further impacted by the types of jobs that are deemed acceptable for women to have. In more developed economies, women are primarily employed in the service sector. Sarkar, Sahoo, and Klasen (2019) analysed employment transitions of working-age women in India. They indicated that women's entry and exit decisions were important when considering the inter-temporal dependence of labour supply decisions. Ismail, Shamsudin, and Chowdhury (2012) explained how the intention of women to become entrepreneurs is stimulated by the push and pull motivations according to the deviation of personal position, nature, and desire. Dettling (2017) added on that the factors affecting the intention for women to become entrepreneurs are economic core, work core, social core, individual core, and entrepreneurial core. Moses and Mordi (2010); Sadi and Al-Ghazali (2010); Sharma, Dua and Hatwal (2012) universally found out that age was one of the pull factors that affect the intention of a woman in becoming an entrepreneur.

Therefore, for this study, women's employment is important because if women's employment could increase, the city's overall productivity will increase. Besides, women could replace less productive men (evidenced by lower male labour force participation rates in recent decades and higher wages for men that remain in the market).

\subsection{Foreign direct investment (FDI)}

FDI is the practice of starting or investing in businesses in foreign countries. For example, if an American multinational firm establishes its operations in Singapore or Malaysia, either by opening up its own premises or by partnering with a local firm, that investment would be considered part of FDI. Economists track the flows of FDI between countries as this is seen as an important contributor to economic growth (BEA, 2019). Erum, Hussain and Yousaf (2016) and Gauchat, Kelly and Wallace (2012) suggested that 
highly skilled women are required for complex jobs. However, Gauchat et al (2012) argued that increasing the demand for high skilled labour might severely damage gender-based occupations in the labour market. This is owing to previous research which does not consider the gendered dimensions of globalisation via FDI. Moreover, they also mentioned that FDI might induce an influx of foreign labour to the host country which would affect local women's employment. Again, Simionescu, Lazányi, Sopková, Dobeš and Balcerzak (2017) mentioned that FDI enables the enhancement of products and employees' quality to meet international standards and improve foreign exchange. There has been a positive relationship between women's employment and FDI in semi-industrialised countries.

Therefore, FDI is an important variable of this study and in terms of women employment and FDI, it is clear that foreign investment in labourintensive, largely export-oriented industries has had a significant impact on women's work and development.

\subsection{GDP growth rate}

GDP is the monetary value of all finished goods and services made within a country during a specific period. The real economic growth rate, or real GDP growth rate, measures economic growth, as expressed by GDP, from one period to another, adjusted for inflation or deflation. In other words, it reveals changes in the value of all goods and services produced by an economythe economic output of a country - while accounting for price fluctuations (Investopedia, 2021). Scurtu and Morosan (2019) aimed to show that the role and place that women obtained, over time, in the process of the state's economic development. They also highlighted some of the most successful women leaders, which through their own pattern of thinking conduct the economic development of the world. Kreishan (2011) and Blanchard and Johnson (2015) outlined that the decomposition of GDP consists of consumption, investment, government spending and trade balance. GDP growth rate means the rate of GDP increases in aggregate output over time. They point out that component consumption had the greatest portion in GDP by accounting for $70.5 \%$. The consumption power strongly relies on disposable income. Tiwari (2019) explained that investing in women can provide a great stimulus to economic growth, known as the "gender dividend". When they are the focus of business decisions, communities also 
grow around them. Moreover, it is estimated that women in India contribute as much as $17 \%$ of national GDP, against the global average of $40 \%$. This illustrates a significant gap which is underutilised in the recovery efforts.

The above, the role of women participating in the country's productivity is one of the economic growth models.

\subsection{Education level (EDU)}

This literature examines the relationship between education and working life. In general, people with higher levels of education have better job prospects; the difference is particularly marked between those who have attained upper secondary education and those who have not (OECD, 2012). Education has a substantial impact on employment prospects. Among those with only a lower secondary education, the employment rate is $69 \%$ for men and $49 \%$ for women; among those with university level education and advanced research programmes, this rises to $88 \%$ for men and $79 \%$ for women. Kargi (2014) and Malik and Jabeen (2020) mentioned that educational level is one of the factors that would affect the labour participation rate. As the educational level increases, the labour participation rate increases which leads to an increment in the labour force. Consequently, increases in educational level have the potential to increase the employment rate. Malec, Gouda, Kuzmenko, Soleimani, Řezbová and Šánová (2016) discovered that the Egyptian economy had issues of quality and the competitiveness of fresh graduates mismatched the skill requirements in private sectors. Hence, these fresh graduates were willing to work for low-quality jobs due to the difficulty of entering the high-quality job market. Osundina (2020) discussed the sustainable development goals had brought about general improvements in the quality of life of females, especially in the aspects of health and education. There were positive and significant relationships among the health status, the level of education and the labour participation rate of females in Nigeria. Employers' demand was also the potential supply of skills available to the labour market. Thus, this literature highlights that female with higher education and appreciable health statuses have better chances of participating in the labour force.

Therefore, education level is a very important factor, and it is a stable supply of well-educated workers to promote economic development. 


\subsection{Women marital status (MARS)}

The model used in Eckstein, Keane and Lifshitz (2019) offered an explanation of women, who are willing to be employed after marriage under a circumstance of receiving a higher level of education. In addition, Juhn and McCue (2011) and Eckstein et al. (2019) found that there was a declination of women's marriage rate. Based on Eckstein et al. (2019) findings, this declination happened among younger-aged women and the key factor of this phenomena was the high maternal education. Dettling (2017) and Vignoli, Matysiak, Styrc, and Tocchioni (2018) found a strong positive relationship between marital disruption and the women's employment rate. In their studies mentioned that the labour market in Italy is still dominated by males as they are the breadwinners. Therefore, this situation leads to women's employment rates that are relatively low. The number of studies examining the relationship between women's employment and marital status is limited in the literature. Telatar (2020) contributed to the literature by including the variable of female employment according to marital status. For this reason, relations between both married and divorced female employees and employment in Turkey were analysed with cointegration tests for the period of 1988-2013. According to the empirical results acquired, there is no long-term relationship from the number of married women to the number of employed women. On the other hand, there is a positive relationship from the number of divorces to the number of employed women.

Therefore, marital status should be considered as one of the factors of women's employment in this study.

\subsection{Fertility rate (FR)}

Fertility is the quality of being able to produce children. As a measure, fertility rate is the average number of children that a woman has in her lifetime and is quantified demographically. Van den Broeck and Maertens (2014) further highlighted that if the fertility rate is reduced; it would then slow down the population growth rate.

Population growth rate and employment rate are as well related. Similar findings were derived by Andersen and Özcan (2021), whereby unemployment rate could affect the total number of births negatively. This is because unemployment is considered as a "family financial crisis", as 
the breadwinner is unable to generate household income to support family expenditures. Thus, the husband and wife would control the number of births. Lam, Sedlacek and Duryea's (2016) research showed that the increase in educational level for both genders led to the reduction of the fertility rate in Brazil. This is because higher educational levels for an employee indicates that a particular employee has a higher salary bargaining power due to his or her highly skilled and competitive labour. Behrman and Gonalons-Pons (2020) combined nationally representative country-level data on women's wage employment from the International Labour Organization (ILO) with fertility and reproductive health measures from the United Nations and additional information from United Nations Educational, Scientific and Cultural Organization (UNESCO), OECD, and the World Bank. This dataset was used to explore the linear association between women's employment and fertility/reproductive health around the world between 1960 and 2015. They found that women's wage employment is negatively correlated with total fertility rates, meant that the wages didn't meet the need for planning a family's cost. This finding was only for non-agricultural employment. Moreover, there is a linear association between women's employment and fertility on a global scale which widens the discussion to also include reproductive health outcomes.

Therefore, the fertility rate needs to be considered in this research as it is important in understanding the mechanisms behind global fertility change.

Figure 2: Model for Sustainability of Women Employment

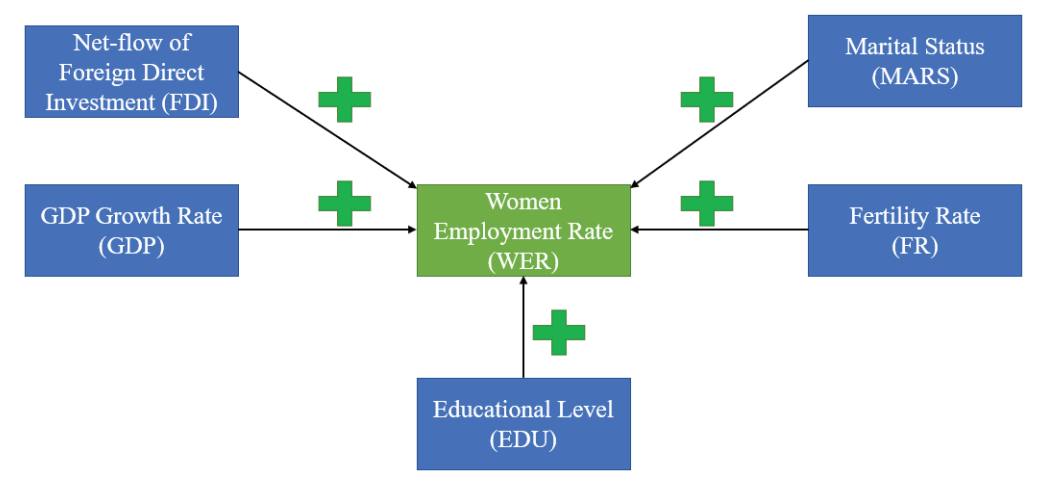

Source: Authors' own model. 


\section{Model and Methodology}

Figure 2 shows a model for sustainability of the women's employment rate developed for this study.

\subsection{Model specification}

$W_{E R}=\beta_{0}+\beta_{1} F D I_{t-1}+\beta_{2} G D P_{t-1}+\beta_{3} E D U_{\mathrm{t}-1}+\beta_{4} M A R S_{t-1}$
$+\beta_{5} F R_{t-1}+\varepsilon_{1 t}$

where:

WER = Women's employment rate $(\%)$;

FDI = Rate of FDI per GDP (\%);

GDP $=$ GDP growth rate $(\%)$;

$\mathrm{EDU}=$ Rate of tertiary education level acquired by women labour (\%);

MARS $=$ Rate of married women in the labour force (\%);

$\mathrm{FR}=$ Fertility rate of women in the labour force (\%);

$\varepsilon=$ Error term; $t=$ Time period; $T=$ Time trend, 1982 to 2018 yearly data

\subsection{Research hypothesis}

According to the conceptual framework (Figure 2), five research hypotheses are derived as follows:

Table 3: Research Hypotheses

\begin{tabular}{cl}
\hline Variables & \multicolumn{1}{c}{ Hypotheses } \\
\hline & $\begin{array}{l}\mathrm{H}_{01}: \text { There is no positive relationship between net-flow of foreign direct } \\
\text { investment (FDI) and the women employment rate (WER) in Malaysia. }\end{array}$ \\
& $\begin{array}{l}\mathrm{H}_{\mathrm{A} 1}: \text { There is a positive relationship between net-flow of foreign direct } \\
\text { investment (FDI) and the women employment rate (WER) in Malaysia. }\end{array}$ \\
& $\begin{array}{l}\mathrm{H}_{02}: \text { There is no positive relationship between GDP growth rate (GDP) } \\
\text { and the women employment rate (WER) in Malaysia. }\end{array}$ \\
& $\begin{array}{l}\mathrm{H}_{\mathrm{A} 2}: \text { There is a positive relationship between GDP growth rate (GDP) } \\
\text { and the women employment rate (WER) in Malaysia. }\end{array}$ \\
& $\begin{array}{l}\mathrm{H}_{03}: \text { There is no positive relationship between educational level (EDU) } \\
\text { and the women employment rate (WER) in Malaysia. }\end{array}$ \\
EDU & $\begin{array}{l}\mathrm{H}_{\mathrm{A} 3}: \text { There is a positive relationship between educational level (EDU) } \\
\text { and the women employment rate (WER) in Malaysia. }\end{array}$
\end{tabular}




\begin{tabular}{|c|c|}
\hline Variables & Hypotheses \\
\hline \multirow{2}{*}{ MARS } & $\begin{array}{l}\mathrm{H}_{04} \text { : There is no positive relationship between women marital status } \\
\text { (MRS) and the women employment rate (WER) in Malaysia. }\end{array}$ \\
\hline & $\begin{array}{l}\mathrm{H}_{\mathrm{A} 4} \text { : There is a positive relationship between women marital status } \\
\text { (MRS) and the women employment rate (WER) in Malaysia. }\end{array}$ \\
\hline \multirow{2}{*}{ FR } & $\begin{array}{l}\mathrm{H}_{05} \text { : There is no positive relationship between fertility rate (FR) and the } \\
\text { women employment rate (WER) in Malaysia. }\end{array}$ \\
\hline & $\begin{array}{l}\mathrm{H}_{A 5} \text { : There is a positive relationship between fertility rate (FR) and the } \\
\text { women employment rate (WER) in Malaysia. }\end{array}$ \\
\hline
\end{tabular}

Source: Authors' own model.

\subsection{Model estimation methods}

Time series yearly data was used to facilitate the analysis of this research. The secondary data was compiled from DOSM portal site and the World Bank website. In this research, 37 years from the year 1982 to 2018 was the period used when collecting the data. In the meantime, according to the World Bank (2020), the female labour force participation rate in Malaysia had increased to $38.9 \%$ in 2019 compared to 2018 , which was less than half of the total labour force in Malaysia. Moreover, limited research data explored the association between the factors and women's employment on a truly global scale due to limited cross-national comparative standardised information across contexts.

The research methods tested for correlation analysis, unit root tests, Johansen Cointegration Rank Test, Vector Error Correction Method (VECM) analysis with error correction model of cointegration equation, residual diagnosis, and model evaluation. The residual diagnosis involved i) Normality test, ii) Autocorrelation test, iii) Heteroskedasticity test, and iv) Multicollinearity test. After raw data had been organised, these data were analyzed using EViews 8 software.

In any research, the existence of long-run relationships between the variables is crucial. Hence, the cointegration analysis was carried out to examine whether the variables have a long-term relationship with each other. According to Studenmund (2017), the cointegrated variables are free from the issue of spurious regression. Based on Gujarati (2015), the Johansen test is separated into two parts, the maximum eigenvalue test and the trace test. According to Stephanie (2016), the Johansen test is able to handle more 
than two variables in estimating all the cointegration vectors. The hypothesis development for the Johansen test is as below:

$\mathrm{H}_{0}$ : There is no cointegration between the variables.

$\mathrm{H}_{\mathrm{A}}$ : There is a cointegration between the variables.

When the p-values in the Johansen test are statistically significant at the level of 0.01 , three asterisk symbols $(* * *)$ will be shown in the probability (p-value) to conclude that variable is cointegrated and to reject $\mathrm{H}_{0}$ and otherwise, to not reject $\mathrm{H}_{0}$. The cointegration relationships can be imposed by re-parameterising the vector autoregression (VAR) model as a VECM. Based on Gujarati (2015), the reason is that the parameters must be estimated consistently before making simultaneous equations. In addition, Studenmund (2017) also mentioned that an under-identified equation is unable to perform Two-Stage Least Squares (2SLS) as the results will be biased. The function of the VAR model is a tool for forecasting and modeling the variables. According to Baum (2013), VECM is adopted when the variables are nonstationary and, if its mean and variance are non-constant over time. VECM model includes two equations, such as VECM equation (Equation 2), which also considers a short-run relationship among the variables, and cointegration equation (Equation 3), which considers a lagged error-correction term to the long-run relationship.

The VECM equation is given below:

$\Delta W E R_{t}=\beta_{6}+\beta_{7} \Delta F D I_{t-1}+\beta_{8} \Delta G D P_{t-1}+\beta_{9} \Delta E D U_{t-1}+$ $\beta_{10} \Delta M A R S_{t-1}+\beta_{11} \Delta F R_{t-1}+\beta_{12} \Delta W E R_{t-1}+\varepsilon_{2 t}$

The co-integration equation is shown below:

$\beta_{13} \Delta W E R_{t-1}+\beta_{14} \Delta F D I_{t-1}+\beta_{15} \Delta G D P_{t-1}+\beta_{16} \Delta E D U_{t-1}+$ $\beta_{17} \Delta M A R S_{t-1}+\beta_{18} \Delta F R_{t-1}=0$

Besides, the Johansen Cointegration Rank Test is also a test of the existence of cointegration equations, and a long-run relationship between the variables. Two types of test statistics are reported. The first block reports the so-called trace statistics, and the second block reports the maximum 
eigenvalue statistics. These values explain more than one cointegrating relationship between the variables. On the other hand, correlation analysis was performed aiming to measure the strength and direction of the linear relationship between two variables (see Studenmund, 2017; Gujarati, 2015). The strength of the relationship between the variables is indicated by the simple correlation coefficient $(\mathrm{r}) . \mathrm{r}=+1$ : the two variables are perfectly positively correlated, $\mathrm{r}=-1$ : the two variables are perfectly negatively correlated and $r=0$ : the two variables are totally uncorrelated. If $r=0$; Do not reject $\mathrm{H}_{0}$; There is no correlation between independent variable and dependent variable. If $\mathrm{r}>0$; Reject $\mathrm{H}_{0}$. There is a correlation between independent variable and dependent variable. Moreover, the unit root test is to ensure the mean and the median of a regression model is constant and not a non-stationary test (Gujarati, 2015). This is because if the relationship between the dependent variable and at least one independent variable is nonstationary, the regression may confront the problem of spurious correlation.

\section{Presentation of Results}

\subsection{Correlation analysis}

Table 4 explains the correlation analysis between the variables. There is a positive and weak correlation between FDI and WER. Also, there is a positive and moderate correlation between GDP, EDU, FR and WER. However, there is a positive and strong correlation between MARS and WER.

Table 4: Correlation Analysis Extract

\begin{tabular}{ccc}
\hline Variables & WER & Strength \\
\hline WER & 1 & - \\
FDI & 0.2479 & Weak Positive Relationship \\
GDP & 0.6672 & Moderate Positive Relationship \\
EDU & 0.6248 & Moderate Positive Relationship \\
MARS & 0.9105 & Strong Positive Relationship \\
FR & 0.6279 & Moderate Positive Relationship \\
\hline
\end{tabular}

Source: Authors' computation. 


\subsection{Model identification (Unit Root Test)}

According to Table 5, the variables FDI and GDP are both stationary at level and statistically significant at 5\% and 1\% for both Augmented Dickey Fuller (ADF) and Phillips Perron (PP) tests. At first difference and second difference, all variables are significant for both ADF and PP tests. Therefore, WER's VECM model will be used for first difference model.

Table 5: Results of Unit Root Tests

\begin{tabular}{clccccc}
\hline & \multicolumn{5}{c}{ ADF } & \multicolumn{3}{c}{ PP } \\
\cline { 2 - 7 } Variables & \multicolumn{1}{c}{ Level } & First & Second & Level & First & Second \\
\hline WER & -1.6520 & $-4.0615^{* *}$ & $-9.3212^{* * *}$ & -1.4864 & $-4.1006^{* *}$ & $-11.3755^{* * *}$ \\
FDI & $-2.9189^{* *}$ & $-6.3821^{* * *}$ & $-7.9702^{* * *}$ & $-2.9509^{* *}$ & $-6.5276^{* * *}$ & $-20.4039^{* * *}$ \\
GDP & $-5.4723^{* * *}$ & $-7.1013^{* * *}$ & $-9.2387^{* * *}$ & $-5.4728^{* * *}$ & $-23.2377^{* * *}$ & $-43.9340^{* * *}$ \\
EDU & 1.5309 & $-5.6384^{* * *}$ & $-6.2127^{* * *}$ & 4.0821 & $-5.6469^{* * *}$ & $-20.8738^{* * *}$ \\
MARS & -1.1566 & $-4.9680^{* * *}$ & $-6.5117^{* * *}$ & -1.4157 & $-5.0986^{* * *}$ & $-11.7879^{* * *}$ \\
FR & -0.3309 & $-7.7836^{* * *}$ & $-8.5823^{* * *}$ & -0.8048 & $-7.8012^{* * *}$ & $-17.2557^{* * *}$ \\
\hline
\end{tabular}

Note: $* * *, * * *$ denote significance level of $10 \%, 5 \%$, and $1 \%$ respectively.

Source: Authors' computation.

\subsection{Johansen cointegration rank test}

Based on Table 6, the trace test shows there are six cointegration equations (CEs) that have long-term relationships between the variables WER, FDI, GDP, EDU, MARS, and FR at a significance level of $\alpha=0.01$. However, the maximum eigen value test in Table 7 shows there are only three CEs that have long-term relationships between the variables WER, FDI, GDP, EDU, MARS, and FR at the significance level of $\alpha=0.01$.

Table 6: Unrestricted Cointegration Rank Test (Trace)

\begin{tabular}{ccccc}
\hline $\begin{array}{c}\text { Hypothesized } \\
\text { No. CE(s) }\end{array}$ & Eigen Value & $\begin{array}{c}\text { Trace } \\
\text { Statistics }\end{array}$ & Critical Value & $\begin{array}{c}\text { Probability } \\
\text { (p-value) }\end{array}$ \\
\hline None $*$ & 0.8185 & 168.9334 & 104.9615 & $0.0000 * * *$ \\
At Most $1 *$ & 0.7298 & 112.6151 & 77.8188 & $0.0000 * * *$ \\
At Most $2 *$ & 0.5873 & 69.4330 & 54.6815 & $0.0002 * * *$ \\
At Most $3 *$ & 0.4018 & 40.2268 & 35.4582 & $0.0022 * * *$
\end{tabular}




\begin{tabular}{ccccc}
\hline $\begin{array}{c}\text { Hypothesized } \\
\text { No. CE(s) }\end{array}$ & Eigen Value & $\begin{array}{c}\text { Trace } \\
\text { Statistics }\end{array}$ & Critical Value & $\begin{array}{c}\text { Probability } \\
\text { (p-value) }\end{array}$ \\
\hline At Most $5^{*}$ & 0.2063 & 7.62576 & 6.6349 & $0.0058^{* *}$ \\
\hline
\end{tabular}

Notes: *denotes rejection of the hypothesis at 0.01 level; **MacKinnon-Haug-Michelis (1999) p-values.

Source: Authors' computation.

Table 7: Unrestricted Cointegration Rank Test (Maximum Eigen Value)

\begin{tabular}{ccccc}
\hline $\begin{array}{c}\text { Hypothesized } \\
\text { No. CE(s) }\end{array}$ & Eigen Value & $\begin{array}{c}\text { Max-Eigen } \\
\text { Statistics }\end{array}$ & Critical Value & $\begin{array}{c}\text { Probability } \\
\text { (p-value) }\end{array}$ \\
\hline None $*$ & 0.8185 & 56.3183 & 45.8690 & $0.0003 * * *$ \\
At Most $1 *$ & 0.7298 & 43.1821 & 39.3701 & $0.0029 * * *$ \\
At Most 2* & 0.5873 & 29.2062 & 32.7153 & $0.0307 * *$ \\
At Most 3* & 0.4018 & 16.9556 & 25.8612 & $0.0174 * *$ \\
At Most 4* & 0.3776 & 15.6455 & 18.5200 & $0.0301 * *$ \\
At Most 5* & 0.2063 & 7.6258 & 6.6349 & $0.0058 * *$ \\
\hline
\end{tabular}

Notes: *denotes rejection of the hypothesis at 0.01 level; **MacKinnon-Haug-Michelis (1999) p-values.

Source: Authors' computation.

\subsection{Co-integration equation}

From equation (4) of the women's employment rate cointegration equation, for EDU and MARS variables, both are cointegrated and have a long-term relationship with WER at $\alpha=0.05$. The variable GDP is also cointegrated and has a long-term relationship with the WER at $\alpha=0.01$.

$$
\begin{array}{ccc}
0.1067 \Delta \text { WER }_{t-1} & -0.1281 \Delta F D I_{t-1}- & 0.4559 \Delta G D P_{t-1}- \\
{[1.7875 *]} & {[-0.5786 n s]} & {[-5.7962 * * *]} \\
0.0135 \Delta E D U_{t-1} & -0.0164 \Delta M A R S_{t-1} & - \\
{[-2.1685 * *} & {[-2.5322 * *]} & {[-0.4243 n s]}
\end{array}
$$

Note: $* * *, * * *$ denote significance levels of $10 \%, 5 \%$, and $1 \%$ respectively. 


\subsection{Vector Error Correction Method (VECM)}

Based on the VECM equation (5) on women employment rate (WER), the model shows the explanatory variable on accuracy for about $37.92 \%$ of variation in the WER equation. The VECM model estimation reveals that FDI $(\Delta \mathrm{FDI})$, GDP $(\triangle \mathrm{GDP})$, and a lag period of WER $(\triangle \mathrm{WER})$ are the most important variables, which are statistically significant at 0.05 level. Thus, for a $1 \%$ increase in $\triangle \mathrm{FDI}$, on average, there is a positive relationship effect of WER by increasing $0.1429 \%$ at the significance level of 0.05 , holding other variables constant. Apart from that, for a $1 \%$ increase in $\triangle \mathrm{GDP}$, on average, there is a positive effect on WER by increasing $0.3272 \%$ at the significance level of 0.05 by holding other variables constant. Lastly, for a $1 \%$ increase in the lagged variable of $\triangle \mathrm{WER}$, on average, there is a negative relationship effect of WER by decreasing $0.5037 \%$ at the significance level of 0.05 by holding other variables constant.

$$
\begin{aligned}
& \Delta W E R_{t}=0.1067+0.1429 \Delta F D I_{t-1}+0.3272 \Delta G D P_{t-1}+0.4694 \Delta E D U_{t-1}+ \\
& {\left[2.0433^{* *}\right] \quad[2.0475 * *] \quad[0.2350 \mathrm{~ns}]} \\
& 0.7205 \Delta M A R S_{t-1}+1.3936 \Delta F R_{t-1}-0.5037 \Delta W E R_{t-1}+0.1118_{\varepsilon t} \\
& \text { [0.4531ns] [0.9349ns] [-2.5538**] }
\end{aligned}
$$

R-squared $=0.3792 \quad$ Adj. R-squared $=0.1682$

Note: $*, * *, * *$ denote significance at $10 \%, 5 \%$, and $1 \%$ respectively.

\subsection{Residual diagnosis}

Based on seven classical assumptions mentioned by Studenmund (2017) and Gujarati (2015), the residuals are normally distributed (assumption VII). The normality of the residuals was justified based on the p-value and Jarque-Bera value. At any statistical significance levels $(\alpha)$, if the p-value or the Jarque-Bera value is greater than the $\alpha$ value, $\mathrm{H}_{0}$ cannot be rejected (Table 8) and the residuals are normally distributed. Otherwise, the residuals are not normally distributed. According to the Classical assumption IV, the observations of the error term are uncorrelated with each other. This is because a random error in the past time period should not influence the residuals in the current time period, especially in a time series model. Studenmund (2017) also explained that the serial correlation outcome falls 
between the range of $-1 \leq \varepsilon t \leq+1$. If residuals are the negative values $(\varepsilon t$ $<0$ ), the residuals would have an unconventional change for a time period. Yet, the residuals with a positive serial correlation $(E t>0)$ would have a conventional change for a time period. Whereas, if a zero serial correlation meets, it is the requirement of the Classical assumption IV.

According to the Classical assumption V, the error term has a constant variance. For a given number of observations for a variable, the variance of the residuals should be distributed in a symmetric manner. As a result, the standard error of the estimators becomes inaccurate and heteroskedasticity occurs. If the $\mathrm{p}$-value of F-statistic is greater than $\alpha$ value, the $\mathrm{H}_{0}$ cannot be rejected (Table 8) and the residuals have no heteroskedasticity. Otherwise, the residuals have heteroskedasticity. In addition, Studenmund (2017) and Gujarati (2015) also added that the sample size should be increased to eliminate the degree of multicollinearity and allow a more explicit estimation. Following the Classical assumption VI, no explanatory variable is a perfect linear function of any other explanatory variables. Therefore, a better way to detect multicollinearity is through performing a Variance Inflation Factor (VIF) test. If the VIF-value is smaller than $5, \mathrm{H}_{0}$ should not be rejected (Table 8) and the residuals have no multicollinearity. Otherwise, residuals have multicollinearity. For detection of residual analysis, the hypothesis developments results are as below:

Table 8: Summary of Residual Diagnosis

\begin{tabular}{|c|c|c|}
\hline Diagnosis Tests & Results & Decision \\
\hline $\begin{array}{l}\mathrm{H}_{0}: \text { There is no } \\
\text { heteroscedasticity } \\
\mathrm{H}_{\mathrm{A}}: \text { There is } \\
\text { heteroscedasticity }\end{array}$ & $\begin{array}{c}\text { F-statistics }=0.5060 \\
\text { p-value }=0.7694\end{array}$ & $\begin{array}{l}\text { p-value }(0.7694)>0.01 \\
\text { Do not reject } \mathrm{H}_{0} . \\
\text { Thus, residuals have no } \\
\text { heteroscedasticity. }\end{array}$ \\
\hline $\begin{array}{l}\mathrm{H}_{0}: \text { There is no } \\
\text { multicollinearity } \\
\mathrm{H}_{\mathrm{A}}: \text { There is } \\
\text { multicollinearity }\end{array}$ & $\begin{array}{l}\text { R-squared }=0.3792 \\
\quad \text { VIF }=1.611\end{array}$ & $\begin{array}{l}\text { VIF }(1.611)<\text { VIF }(5) \\
\text { Do not reject } \mathrm{H}_{0} . \\
\text { Thus, residuals have no } \\
\text { multicollinearity. }\end{array}$ \\
\hline $\begin{array}{l}\mathrm{H}_{0}: \text { There is normal } \\
\text { distribution } \\
\mathrm{H}_{\mathrm{A}}: \text { There is no normal } \\
\text { distribution }\end{array}$ & $\begin{array}{c}\mathrm{JB}=1.8777 \\
\text { p-value }=0.3911\end{array}$ & $\begin{array}{c}\text { p-value }(0.3911)>0.01 \\
\text { Do not reject } \mathrm{H}_{0} . \\
\text { Thus, residuals are normally } \\
\text { distributed. }\end{array}$ \\
\hline $\begin{array}{l}\mathrm{H}_{0}: \text { There is no serial } \\
\text { correlation } \\
\mathrm{H}_{\mathrm{A}}: \text { There is serial } \\
\text { correlation }\end{array}$ & $\begin{array}{c}\text { F- } \text { - } \text { p-vatistics }=2.5524 \\
\text {-value }=0.1210\end{array}$ & $\begin{array}{c}\text { p-value }(0.1210)>0.01 \\
\text { Do not reject } \mathrm{H}_{0} . \\
\text { Thus, residuals have no serial } \\
\text { correlation. }\end{array}$ \\
\hline
\end{tabular}

Source: Authors' computation. 


\subsection{Model evaluation}

Finally, for model evaluation, it consists of four components namely i) Root Mean Square Error (RMSE), ii) Mean Absolute Error (MAE), iii) Mean Absolute Percentage Error (MAPE), and iv) U-Theil criteria. According to Stephanie (2016), RMSE is a measure to observe the distribution of residuals around the regression line. If the residuals are distributed closer to the zero regression line; the estimation is more accurate due to a high concentration of data that converge around the best fit line. Also, Hyndman and Koehler (2006) revealed that RMSE is a better measure than MAE because MAE is very sensitive to the presence of outliers. Apart from RMSE, MAPE is an alternative method to measure the model accuracy by taking the absolute values of the errors multiply by 100 for percentage. The objective for MAPE is to detect biases for forecasting method. However, it seems easy to interpret as a MAE that is small and close to zero is considered an unbiased estimation; whereas a large positive or negative value of MAE indicates the method is either underestimating or overestimating. According to Cook (2006), if the U-value is close to or equal to zero, following the estimation error, it can be said that the model estimation performance is excellent. Otherwise, if the U-value is close to or equal to 1 , the estimation performance can be said to be bad. The model evaluation of the women's employment rate is shown in Figure 3.

Figure 3 shows that the women's employment rate model has computed values of RMSE, MAE, MAPE and U-Theil that are close to zero. In short, it can be concluded that the performance of this model is satisfactory and valid.

Figure 3: Model Evaluation of Women Employment Rate

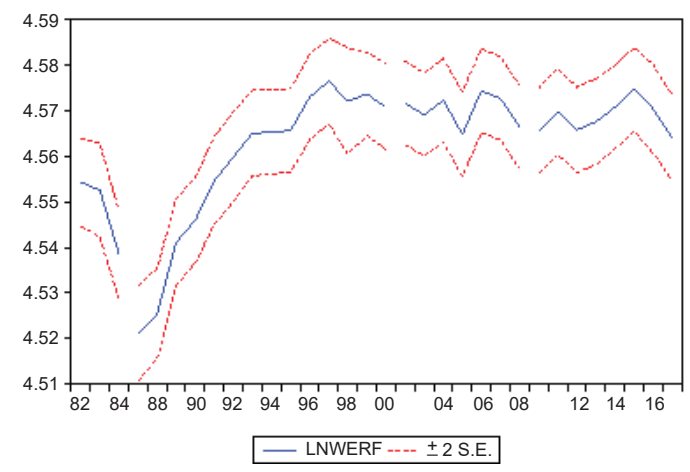

Forecast: LNWERF

Actual: LNWER

Forecast sample: 19822017

Adjust sample: 19822017

Included observations: 32

Root Mean Squared Error 0.003936

M ean Abbsolute Error $\quad 0.003371$

$M$ ean Abs. Percent Error 0.073897

Theil Inequality Coefficient 0.000431

Bias Proportion $\quad 0.000000$

Variance Proportion $\quad 0.019496$

Covariance Proportion 0.980504

Source: Authors' computation. 


\subsection{Hypothesis testing}

From Table 9, and WER's VECM equation, the results of hypothesis testing revealed that there is a positive relationship between FDI and WER for hypothesis $\mathrm{H}_{\mathrm{A1}}$. Also, there is a positive relationship between GDP and WER for hypothesis $\mathrm{H}_{\mathrm{A} 2}$. Therefore, the positive relationships between FDI, GDP and WER are supported and $\mathrm{H}_{0}$ is rejected. The rest of the hypotheses do not reject $\mathrm{H} 0$.

Table 9: Results of Hypothesis Testing for Women Employment Rate

\begin{tabular}{clc}
\hline Variables & \multicolumn{1}{c}{ Descriptions } & \multicolumn{1}{c}{$\begin{array}{c}\text { Decisions } \\
\text { (Supported/Rejected) }\end{array}$} \\
\hline FDI & $\begin{array}{l}\text { HA1: There is a positive relationship between } \\
\text { FDI and WER }\end{array}$ & Supported \\
GDP & $\begin{array}{l}\text { HA2: There is a positive relationship between } \\
\text { GDP and WER. }\end{array}$ & Supported \\
EDU & $\begin{array}{l}\text { HA3: There is a positive relationship between } \\
\text { EDU and WER }\end{array}$ & Rejected \\
MARS & $\begin{array}{l}\text { HA4: There is a positive relationship between } \\
\text { MARS and WER. }\end{array}$ & Rejected \\
FR & $\begin{array}{l}\text { HA5: There is a positive relationship between } \\
\text { FR and WER. }\end{array}$ & Rejected \\
\hline
\end{tabular}

Source: Authors' computation

\section{Discussion and Findings}

Based on the cointegration analysis, the variables of GDP, EDU and MARS, are all cointegrated and have long-term relationships with WER. Furthermore, according to the VECM model estimation, FDI, GDP and lag period of WER have short-term relationships with WER.

The findings show that the variable FDI is significant. Thus, there is a positive relationship between net-flow of FDI and the WER in Malaysia. Therefore, hypothesis $H_{1}$ is accepted. Similar results were also obtained from the test conducted by Herrera-Echeverri, Haar and Estévez-Bretón (2014), Gauchat et al. (2012), and Khosravi and Karimi (2010). Based on their studies, it was revealed that women in the labour force benefited from the spillover effects of FDI. This is because of the effect of knowledge sharing 
and technology transfer by foreign firms improves women's competitive advantages in the workforce. From the perspective of knowledge sharing, women workers can benefit from attending specific trainings provided by the company. For instance, trainings related to soft skills or hard skills can be very enriching. In fact, the quality of labour should be balanced by both hard skills and soft skills. Nowadays, local companies in Malaysia also highly emphasise acquiring hard skills. In layman's term, companies in Malaysia prefer labour with work experience. Therefore, a competent women workforce is important and, thus the demand for women's labour increases.

In addition, the results revealed that the variable GDP is significant. Thus, hypothesis $\mathrm{H}_{2}$ is accepted. Hence, there is a positive relationship between the GDP growth rate and women's employment rate in Malaysia. This result is supported by Vacaflores (2011), Belloumi (2014), Fisher, Johnson and Smeeding (2013), Nurudeen and Usman (2010), and Heathcote, Storesletten and Violante (2017). According to those studies, economic growth causes a reduction in the unemployment rate. In a nutshell, the net-flow of FDI and GDP growth rate seem to be significant factors that contribute to women's employment in various industries in Malaysia.

\section{Conclusion and Recommendations}

It is noteworthy that the economic growth rate seems to affect the women's employment rate. The Malaysian government has already launched several programmes for women, including the Impact for Humanity Woman (IR) 4.0 to embrace rapid technological progress. In conclusion, Malaysia is taking continuous steps to leverage on women given that they are an important pillar for economic growth and sustainability.

\subsection{Theoretical implication}

Theoretically, the greater the economic growth rate, the lower the change of unemployment rate in a country. Therefore, the employment rate is increased by obeying the Okun's Law, as discussed by Blanchard and Johnson (2015). Assuming that the economic activities in Malaysia will increase, the quality of the labour will be enhanced. In the macroeconomic context, GDP is made up of consumption, investment, public spending, and net export. The point of view from Belloumi (2014) was that the component of consumption 
is a major factor that affects GDP. This is because the consumption in a country contributes to about $60 \%$ of GDP. In fact, Cook (2006) revealed that the higher the disposable household income, the greater the household consumption. The research findings obtained are consistent with the Okun's Law, whereby a $1 \%$ decrease in the unemployment rate potentially increases the GDP growth by two percentage points. However, this impact is subject to the location, method, and period of the study. The findings from this study produce a similar impact.

\subsection{Practical implication}

In terms of practical implication, the findings highlight that the government could develop some beneficial policies aimed at mitigating gender bias at the workplace. According to Agénor, Ozdemir, and Pinto Moreira (2021), this type of policy is capable to promote growth and is significantly magnified through a stronger presence of skilled women in the labour market. In fact, this positive potential trade-off may emerge with respect to female unemployment when anti-discrimination policies are combined with government policies with the aim of subsidising women's training. To internalise this trade-off, anti-discrimination policies in the marketplace may need to be complemented by measures aimed at reducing labour costs and raising productivity. Herrera-Echeverri et al., (2014) and Khosravi and Karimi (2010) also revealed that the government policy plays a crucial role in boosting economic growth. This is because, a good fiscal policy should be able to stimulate economic growth by increasing public spending and reducing taxes. Consequently, the disposable household income will be increased and thereby providing a boost to household consumption. Furthermore, an increase in public spending means more investments in the education system, infrastructure development, among others.

\section{Directions for Future Research}

This study mainly focused on the Malaysian context and made no attempt to perform any comparison with other countries in the region. Henceforth, future research should consider a comparative analysis with other countries in similar regions. Comparative studies can provide insightful findings on women's employment in Malaysia. 


\section{Acknowledgement}

The authors are grateful to the Universiti Tunku Abdul Rahman (UTAR) for supporting this research.

\section{Conflicts of Interest}

The authors declare no conflict of interest.

\section{References}

Andersen, S. H., \& Özcan, B. (2021). The effects of unemployment on fertility. Advances in Life Course Research, 100401, 47(1), 1-16.

Agénor, P. R., Ozdemir, K. K., \& Pinto Moreira, E. (2021). Gender gaps in the labour market and economic growth. Economica, 88(350), 235-270.

Baum, C. F. (2013). VAR, SVAR and VECM Models, EC 823: Applied Econometrics Boston College, Spring 2013. Retrieved from http:// fmwww.bc.edu/ECC/S2013/823/ EC823.S2013.nn10.slides.pdf

Belloumi, M. (2014). The relationship between trade, FDI and economic growth in Tunisia: An application of the autoregressive distributed lag model. Economic Systems, 38(2), 269-287.

Blanchard, O. \& Johnson, D.R. (2015). Wage Determination. In Blanchard, O. \& Johnson, D.R. (Ed.s) Macroeconomics. Fifth Canadian edition, (pp. 171-173), Pearson.

Bryant, J., Jacobsen, V., Bell, M., \& Garrett, D. (2004). Labour force participation and GDP in New Zealand (No. 04/07). New Zealand Treasury Working Paper.

Bureau of Economic Analysis (BEA). (2019). "Direct Investment by Country and Industry, 2019". Retrieved from https://www.bea.gov/news/2020/ direct-investment-country-and-industry-2019..

Behrman, J., \& Gonalons-Pons, P. (2020). Women's employment and fertility in a global perspective (1960-2015). Demographic Research, 43, 707744.

Chant, S., \& Sweetman, C. (2012). Fixing women or fixing the world? 'Smart economics', efficiency approaches, and gender equality in development. Gender \& Development, 20, (3)517-529. 
Cook, S., (2006). Understanding the Construction and Interpretation of Forecast Evaluation Statistics Using Computer- Based Tutorial Exercises. Retrieved from https://www.economicsnetwork.ac.uk/showcase/cook_ forecast.

Department of Statistics Malaysia. (2021). Time Series Data. Retrieved from https://www.dosm.gov.my/v1/index.php?r=column/ctimeseries\&menu_id =bnk3bk0wTTkxOXVHaVg3SUFDMIBUUT09.

Dettling, L. J. (2017). Broadband in the labour market: the impact of residential high-speed internet on married women's labour force participation. ILR Review, 70(2), 451-482.

Duflo, E. (2012). Women empowerment and economic development. Journal of Economic Literature, 50(4), 1051-79.

Eckstein, Z., Keane, M., \& Lifshitz, O. (2019). Career and family decisions: Cohorts born 1935-1975. Econometrica, 87(1), 217-253.

Erum, N., Hussain, S., \& Yousaf, A. (2016). Foreign direct investment and economic growth in SAARC countries. Journal of Asian Finance, Economics and Business (JAFEB), 3(4), 57-66.

Fisher, J. D., Johnson, D. S., \& Smeeding, T. M. (2013). Measuring the trends in inequality of individuals and families: Income and consumption. American Economic Review, 103(3), 184-88.

Gauchat, G., Kelly, M., \& Wallace, M. (2012). Occupational gender segregation, globalization, and gender earnings inequality in US metropolitan areas. Gender \& Society, 26(5), 718-747.

Gemelli M. (2014). Women's Employment. In Michalos A.C. (eds) Encyclopedia of Quality of Life and Well-Being Research. Dordrecht: Springer. . https://doi.org/10.1007/978-94-007-0753-5_3251

Gujarati, D. (ed.) (2015). Econometrics By Example (2nd ed.), Palgrave.

Heathcote, J., Storesletten, K., \& Violante, G. L. (2017). The macroeconomics of the quiet revolution: Understanding the implications of the rise in women's participation for economic growth and inequality. Research in Economics, 71(3), 521-539.

Herrera-Echeverri, H., Haar, J., \& Estévez-Bretón, J. B. (2014). Foreign direct investment, institutional quality, economic freedom and entrepreneurship in emerging markets. Journal of Business Research, 67(9), 1921-1932.

Hyndman, R. J., \& Koehler, A. B. (2006). Another look at measures of forecast accuracy. International Journal of Forecasting, 22(4), 679-688. 
Ismail, H. C., Shamsudin, F. M., \& Chowdhury, M. S. (2012). An exploratory study of motivational factors on women entrepreneurship venturing in Malaysia. Business and Economic Research, 2(1), 1-13.

Investopedia. (2021). What Is the Real Economic Growth Rate? Retrieved from https://www.investopedia.com/terms/r/realeconomicrate.asp

Juhn, C., \& McCue, K. (2011). Marriage, employment and inequality of women's lifetime earned income. NBER Papers on Retirement Research Centre Projects, No. NB11-07, September. pp. 1-29.

Kargi, B. (2014). Labour force participation rate and economic growth: observations for Turkey. Universal Journal of Management and Social Sciences, 4(4), 46-54.

Khosravi, A., \& Karimi, M. S. (2010). To investigation the relationship between monetary, fiscal policy and economic growth in Iran: Autoregressive distributed lag approach to cointegration. American Journal of Applied Sciences, 7(3), 415.

Kreishan, F. M. (2011). Economic growth and unemployment: An empirical analysis. Journal of Social Sciences, 7(2), 228-231.

Lam, D., Sedlacek, G., \& Duryea, S. (2016). Increase in women's education and fertility decline in Brazil. Anais, 1, 89-118.

Malec, K., Gouda, S., Kuzmenko, E., Soleimani, D., Řezbová, H., \& Šánová, P. (2016). GDP development and employment in Egypt (2000-2013). International Journal of Economics and Financial Issues, 6(1), 199-206.

Malik, M. A. U. D., \& Jabeen, H. (2020). Higher Education in India: Women Economic Employment. International Journal of Economics and Financial Issues, 1(3), 191-200.

Martins, P. S. (2021). Working to get fired? Unemployment benefits and employment duration. Journal of Policy Modeling, 43(2), 1-15.

Moses, C., \& Mordi, C. (2010). Women entrepreneurship development in Nigeria: The effect of environmental factors. BULETINUL Universitatii Petrol Gaze din Ploie ti, 62(4), 43-52.

Nurudeen, A., \& Usman, A. (2010). Government expenditure and economic growth in Nigeria, 1970-2008: A disaggregated analysis. Business and Economics Journal, 2010(4), 1-11.

OECD. (2012). How does education affect employment rates? In Education at a Glance 2012: Highlights. Paris: OECD Publishing. Retrieved from https://doi.org/10.1787/ eag_ highlights-2012-en

Osundina, O. A. (2020). Sustainable development: Does improvement 
in education and health of women improve female labour force participation rate? Sustainable Development, 28(1), 13-24.

Qinfen, M. (2017). Female labour force participation in Malaysia: timeseries evidence. South East Asia Journal of Contemporary Business, Economics and Law, 14(3).

Raman, K., Anantharaman, R. N., \& Jayasingam, S. (2008). Motivational factors affecting entrepreneurial decision: A comparison between Malaysian women entrepreneurs and women non entrepreneurs. Communications of the IBIMA, 2(12), 85-89.

Sadi, M. A., \& Al-Ghazali, B. M. (2010). Doing business with impudence: A focus on women entrepreneurship in Saudi Arabia. African Journal of Business Management, 4(1), 1-11.

Sarkar, S., Sahoo, S., \& Klasen, S. (2019). Employment transitions of women in India: A panel analysis. World Development, 115, 291-309.

Scurtu, L. E., \& Morosan, G. (2019). Women's contribution to Romania's GDP creation. Ecoforum Journal, 8(1). Retrieved from http:// ecoforumjournal.ro/index.php/eco/article/ view/937

Sharma, A., Dua, S., \& Hatwal, V. (2012). Micro enterprise development and rural women entrepreneurship: way for economic empowerment. Arth Prabhand: A Journal of Economics and Management, 1(6), 114-127.

Simionescu, M., Lazányi, K., Sopková, G., Dobeš, K., \& Balcerzak, A. P. (2017). Determinants of economic growth in V4 Countries and Romania. Journal of Competitiveness. 9(1), 103-116.

Stephanie. (2016). Cointegration: Definition, Examples, Tests. Retrieved from https://www.statisticshowto.datasciencecentral.com/cointegration/

Stephanie. (2016). RMSE: Root Mean Square Error. Retrieved from https:// www.statisticshowto.datasciencecentral.com/rmse/

Studenmund, A. H., (2017). Stationary and Nonstationary Time Series, In Studenmund, A. H. (Ed.) Using Econometrics A Practical Guide, (pp. 402-411), Pearson.

Studenmund, A. H., (2017). Forecasting. In Studenmund, A. H. (Ed.) Using Econometrics A Practical Guide, (pp. 484 - 496), Pearson.

Studenmund, A. H., (2017). The Simple Coefficient, r. In Studenmund, A. H. (Ed.) Using Econometrics A Practical Guide, (pp. 54), Pearson.

Tiwari, H. (2019). Encounters with gendered realities in career decisionmaking while scouting women participation in the Indian workforce. Business Perspectives and Research, 7(2), 147-162. 
Telatar, O. M. (2020). The relationship between women's employment and divorce: An empirical analysis on Turkey. Uluslararası Ekonomi ve Yenilik Dergisi, 6(1), 143-155.

Vacaflores, D. E. (2011). Was Latin America correct in relying in foreign direct investment to improve employment rates? Applied Econometrics and International Development, 11(2), 101-122.

Van den Broeck, G., \& Maertens, M. (2014). Does female employment reduce fertility rates? Evidence from the Senegalese horticultural export sector (No. 727-2016-50359).

Vignoli, D., Matysiak, A., Styrc, M., \& Tocchioni, V. (2018). The positive impact of women's employment on divorce: Context, selection, or anticipation? Demographic Research, 38, 1059-1110.

World Bank. (2020). Female Labour force (\% of total labour force) Malaysia. Retrieved from https://data.worldbank.org/indicator/SL.TLF. TOTL.FE.ZS?locations $=$ MY 